\title{
Kars İli Sarıkamış İlçesi İçme Suyu Arıtma Tesisi Giriş ve Çıkış Su Kalitesinin Aylara Göre Değişiminin İncelenmesi
}

\author{
Şahset İRDEMEZ ${ }^{1 *}$, Hacer ÖZGER ${ }^{1}$, Fatma EKMEKYAPAR TORUN ${ }^{1}$, Sinan KUL $^{2}$ \\ ${ }^{I}$ Atatürk Üniversitesi Mühendislik Fakültesi Çevre Mühendisliği Bölümü, Erzurum \\ ${ }^{2}$ Bayburt Üniversitesi Uygulamalı Bilimler Fakültesi Acil Yardım ve Afet Bölümü, Bayburt \\ (0000-0002-0205-4630)-(0000-0002-4402-7200)-(0000-0002-2289-176X)-(0000-0002-7824-756X)
}

\begin{abstract}
$\ddot{O} \mathbf{z}$
Bu çalışmada Kars ili sınırları içerisinde yer alan Sarıkamış Belediyesi İçme Suyu Arıtma Tesislerinde arıtılan suyun fiziksel ve kimyasal özelliklerine ilişkin tesis giriş ve çıkış değerleri karşılaştırılarak bu değerlerin içme suyu standartlarına uygunluğunun değerlendirilmesi amaçlanmıştır. Bu amaçla Temmuz 2017-Haziran 2018 dönemini kapsayan aylık periyotlarda, tesisin giriş ve çıkış sularından elde edilen numunelerde $\mathrm{pH}$, sıcaklık, elektriksel iletkenlik, renk, alkalinite, nitrit, bulanıklık, demir, organik madde miktarı, sülfat, mangan, amonyum ve alüminyum gibi içme suyu parametrelerinin analizleri yapılmıştır. Çalışmada elde edilen veriler TS 266 ve İnsani Tüketim Amaçlı Sular Hakkında Yönetmelik ile karşılaştırılmış ve sonuçların sıcaklık parametresi dışında tüm su kalitesi standartlarını sağladığı anlaşılmıştır.
\end{abstract}

Anahtar kelimeler: Arıtma tesisi, aylık değişim, içme suyu standartları, su kalitesi.

\section{Investigation of the Monthly Variation in Inlet and Outlet Water Quality of Drinking Water Treatment Plant of Sarıkamış District of Kars Province}

\begin{abstract}
In this study, it is aimed to evaluate the compliance of these values with drinking water standards by comparing the physical and chemical properties of the water treated in Sarıkamış Municipality Drinking Water Treatment Plants within the borders of Kars. For this purpose, in monthly periods covering the period from July 2017 to June 2018, analyzes of drinking water parameters such as $\mathrm{pH}$, temperature, electrical conductivity, color, alkalinity, nitrite, turbidity, iron, organic matter, sulphate, manganese, ammonium and aluminum were conducted in the samples obtained from the inlet and outlet waters of the facilities. The data obtained in the study were compared with TS 266 and Regulation Concerning Water Intended for Human Consumption and it was concluded that the results conformed to all water quality standards except the temperature parameter.
\end{abstract}

Keywords: Drinking water standards, monthly change, treatment plant, water quality.

\section{Giriş}

Su, her ne kadar sıradan bir bileşik olarak görünse de canlıların yaşamlarını sürdürmek için en önemli maddelerden birisi olup, gündelik yaşamda içme, yıkama, pişirme, yıkanma, yüzme gibi birçok faaliyet su ile gerçekleştirilmektedir. Bilinen yaşam su sayesinde evrimleşmiştir ve su olmadan canlllık sürdürülememektedir. Kuraklıklar kıtlıklara, seller ise ölüm ve hastalıklara neden olmaktadır. Açıkça görülen önemi nedeniyle su, dünya üzerinde en fazla çalışılan materyal konumundadır [1].

Dünyada bulunan toplam su miktarının 1,4 milyar $\mathrm{km}^{3}$ olduğu bilinmektedir. Bu su miktarının yaklaş1k \%97,5'inin okyanuslar ve denizlerde tuzlu su olarak, \%2,5'inin ise nehirler ve göllerde tatlı su şeklinde bulunduğu belirtilmektedir. Tatlı suyun tuzlu suya göre oranının önemli düzeyde az oluşunun yanı sıra su kaynaklarının \%90'lık bölümünün kutuplar ve yeraltında mevcut olması nedeniyle insanların kolayca faydalanabileceği tatlı suya ulaşılabilirliğin zor olduğu açık bir şekilde görülebilmektedir [2]. Bu su kitlığına ilaveten küresel ölçekte su kullanımı son 100 yılda 6 kat artmış ve yılda yaklaşık \%1 oranında istikrarlı bir şekilde artmaya devam etmektedir. Günümüzde küresel su 
talebinin yılda yaklaşık $4600 \mathrm{~km}^{3}$ olduğu tahmin edilmekte ve 2050 yılına kadar yılda \%20-30 artarak 5500 ile $6000 \mathrm{~km}^{3}$ arasında bir değere çıkacağı öngörülmektedir. 2 milyardan fazla insan güvenli içme suyuna erişememekte, 4 milyardan fazla insan ise güvenilir düzeyde sanitasyona erişememektedir [3].

Dünyada yıllık olarak birey başına düşen kullanılabilir su miktarının $1000 \mathrm{~m}^{3}$ 'ün altında olduğu ülkeler su fakiri, $2000 \mathrm{~m}^{3}$ ’ün altında olduğu ülkeler ise su azlığı çeken ülkeler olarak nitelendirilmekte olup Türkiye'de tüketime elverişli yeraltı ve yüzey sularının yıllık ortalaması 112 milyar $\mathrm{m}^{3}$ ve bu miktarın yaklaşık \%40'ının kullanılabildiği bilinmektedir. Türkiye, yıllık olarak birey başına düşen kullanılabilir su miktarının yaklaşık $1519 \mathrm{~m}^{3}$ olması bakımından su azlığı çeken ülke kategorisinde yer almaktadır [4]. Yeraltı ve yüzeysel kaynaklardan temin edilen su, doğada sürekli sirkülasyon halinde olması nedeniyle tüketim noktalarına ulaşana kadar fiziksel, kimyasal ve mikrobiyolojik ajanlar tarafından kirlenmekte ve hijyen açısından ciddi sağlık sorunlarına yol açabilmekte olup genel anlamda suyun fiziksel, kimyasal ve mikrobiyolojik özellikleri olmak üzere üç farklı karakteristiği bulunmaktadır [5].

Suyun temel fiziksel özellikleri sıcaklık, renk, bulanıklık, koku ve tat, temel kimyasal özellikleri ise $\mathrm{pH}$, elektriksel iletkenlik, tuzluluk, alkalinite, sertlik, iyonlar, ağır metaller ve çözünmüş oksijen (ÇO) olarak sıralanabilmektedir[6-9]. Son olarak suyun mikrobiyolojik özellikleri ise canlı bünyeleri, toprak, su vb. ortamların çokluğu nedeniyle çeşitlilik göstermektedir [10]. TS 266'ya göre suyun mikrobiyolojik özellikleri arasında toplam koliform ve toplam bakteri sayılarına ilişkin özellikler bulunmaktadır [11].

Kabul edilebilir içme suyu kalitesi kullanım için uygun fiziksel, kimyasal ve mikrobiyolojik içme suyu standartları ile mümkün olabilmektedir. İçilebilir suyun sıcaklığ $17-12^{\circ} \mathrm{C}$ aralığında ve hijyen bakımından suyun görünümünün berrak olması gerekmektedir. Genellikle yüksek kaliteli su kokusuz olup suyun lezzetinin doğal ve içiminin hoş olması gereklidir. Suyun pH'sı nötr ya da hafif düzeyde alkali olmalıdır [10]. Günümüzde Dünya Sağlık Örgütü (WHO) ve Çevre Koruma Ajansı (EPA) tarafından belirlenen içme suyu standartları kullanılmaktadır. Türkiye'de içme suyu kalitesinin değerlendirilmesinde ise TS266 ve İnsani Tüketim Amaçlı Sular Hakkında Yönetmelik olmak üzere iki temel standart bulunmaktadır.

Bu çalışmada, Kars ilinin Sarıkamış ilçesinde bulunan bir içme suyu arıtma tesisinde arıtılan suyun fiziksel ve kimyasal özelliklerine ilişkin tesis giriş ve çıkış değerlerinin ortaya konması ve bu değerlerin içme suyu standartlarına göre değerlendirilmesi amaçlanmıştır. Bu amaç doğrultusunda içme suyu numunelerinin tesis giriş ve çıkış parametreleri Temmuz 2017-Haziran 2018 tarihleri arasında farklı mevsimlerde elde edilen su numunelerinden toplanmış ve böylece mevsimsel değişim izlenmiştir.

\section{Materyal ve Metot}

\subsection{Sarıkamış Belediyesi İçme Suyu Arıtma Tesisi}

Günlük 18,144 $\mathrm{m}^{3}$ suyu arıtacak şekilde tasarlanmış olan Sarıkamış Belediyesi İçme Suyu Arıtma Tesisi 40,345829 enlem ve 42,587521 boylamda yer almakta olup Şekil 1'de araştırma sahasının haritada konumu gösterilmektedir [12]. Mevcut hali ile ham su kaynağı olarak Kızılçubuk, Çataldere, Acısu ve Kut derelerinden su temin edilmektedir. Tesise giren ham su sirasıyla havalandırma, ön klorlama, koagülasyon-flokülasyon, kimyasal çöktürme, filtrasyon, geri yıkama ve son klorlama işlemlerinden geçirilerek içme suyu standartlarına uygun hale getirilmekte ve temiz su deposundan cazibeyle şehir şebekesine verilmektedir.

\subsection{Araştırmada İçme Suyu Analizlerinde Kullanılan Yöntemler}

Araştırmada 2017 Temmuz ayından 2018 Haziran ayına kadar her ayın aynı tarihlerinde tesis giriş ve çıkışlarından numuneler alınarak karşılaştırılan içme suyu parametreleri; $\mathrm{pH}$, sıcaklık, elektriksel iletkenlik, renk, alkalinite, nitrit, bulanıklık, demir, organik madde miktarı, sülfat, mangan, amonyum ve alüminyum olarak sıralanmakta olup analizler standart metotlara uygun olarak yapılmıştır. $\mathrm{pH}$ ve iletkenlik analizleri, WTW ProfiLine pH 3110 multimetre kullanilarak, diğer analizler standart metotlarda belirtildiği gibi yapılmıştır [13]. 


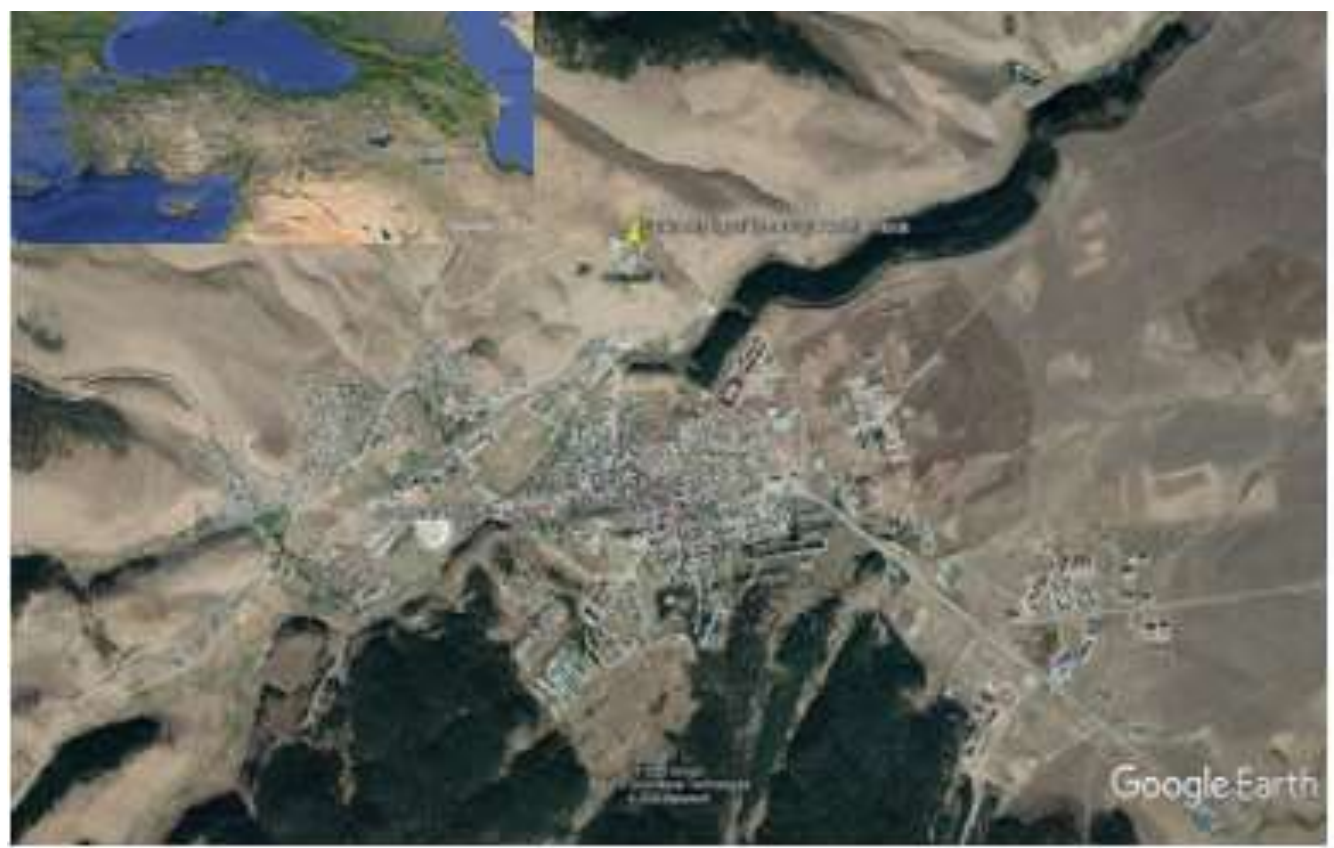

Şekil 1. Araştırma sahasının uydu görünümü

\section{Bulgular ve Tartışma}

\subsection{Suyun Fiziksel Özelliklerine İliş̧kin Bulgular}

Araştırmada arıtma tesisine gelen ham su ve arıtma tesisinden çıkan arıtılmış içme suyu numunelerinin bulanıklık, sıcaklık, renk gibi fiziksel özelliklerine ilişkin değerler karşılaştırılmış ve Şekil 2-4'de gösterilmiştir.

\subsubsection{Bulanıklık verilerine ilişkin bulgular}

Su numunelerinde bulunan askıda katı maddeler (AKM), sularda 1şık geçirgenliğini azaltmanın yanı sıra suyun filtre ve dezenfekte edilebilirliğinin de azalmasına sebep olmakta olup, çalışmada bulanıklık verileri için elde edilen sonuçlar Şekil 2'de gösterilmektedir.

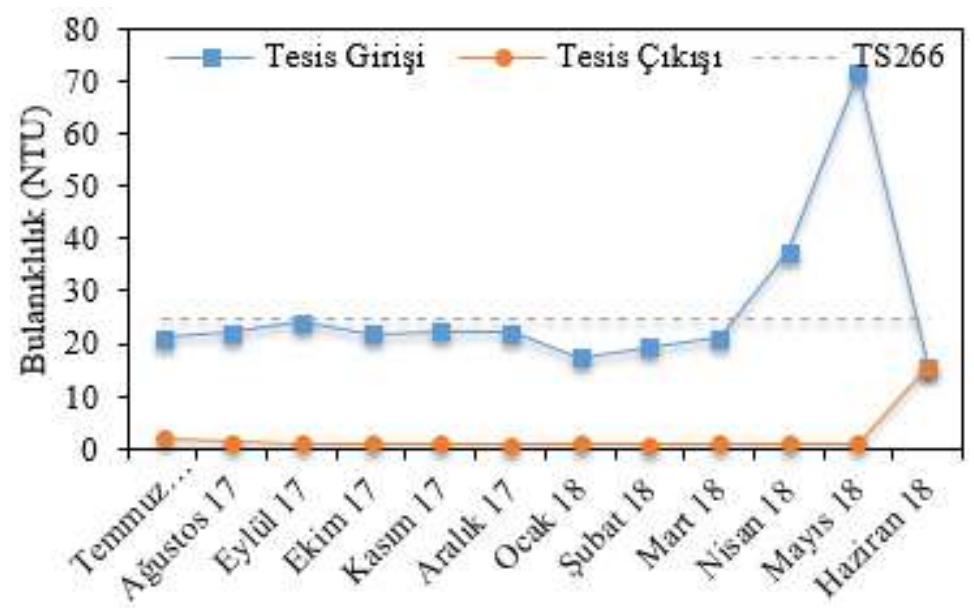

Şekil 2. Su numunelerinin bulanıklık değerlerinin aylara göre değişimi

Şekil 2 ayrıntılı olarak incelendiğinde temmuz ayında tesise gelen su için bulanıklık değeri 21,09 NTU iken, çıkış suyu değeri ise 2,01 NTU olarak ölçülmüştür. Mart ayına kadar sabit bir eğilim izleyen bulanıklık değerlerinin nisan ayında artış göstermeye başlamıştır. Mayıs ayında tesise gelen suyun bulanıklık değeri 71,52 NTU, çıkış değeri 0,98 NTU olup, haziran ayında keskin bir düşüşle tesise gelen 
suyun bulanıklık değeri 15,50 NTU ve çıkış değeri 15,66 NTU olarak gerçekleşmiştir. Literatürde yağışların az veya hiç olmadığı dönemlerde bulanıklık seviyelerindeki düşüşün aksine, yağışlı dönemlerde bulanıklık değerlerinde artış meydana geldiği bildirilmektedir. Dahası tipik olarak akarsuların kaynağından uzaklaştıkça bulanıklık artmaktadır [14]. Buna göre tesislerde ölçülen bulanıklık değerlerinin mart ayından itibaren artmaya başlamasındaki temel nedenlerin, kış aylarında yağan karların erimeye başlaması ve ilkbahar mevsiminde yağmur yağışının fazla olmasından kaynaklandığı düşünülmektedir. Aynı şekilde mayıs ve haziran ayları arasında tesiste biriken çökelti çamurlarının tahliye edilmesi sonucu, su bulanıklığının tesis çıkışında artış gösterdiği düşünülmektedir. Benzer şekilde haziran ayında karların büyük oranda erimiş olması ve yağış miktarlarının düşmesi nedeniyle giriş suyu bulanıklı̆̆ında azalmanın görüldüğü söylenebilir. Çıkış suyunda ölçülen bulanıklık değerlerinin TS 266'ya göre 5-25 NTU aralığında olduğu belirlenmiştir.

\subsubsection{Sıcaklık verilerine ilişkin bulgular}

Su numunelerinde sıcaklık, gazların çözünürlüğü ve biyolojik prosesler açısından önemli bir parametre olup, arıtma tesislerinin giriş ve çıkışlarında ölçülen su sıcaklığına ilişkin bulgular Şekil 3'de gösterilmiştir.

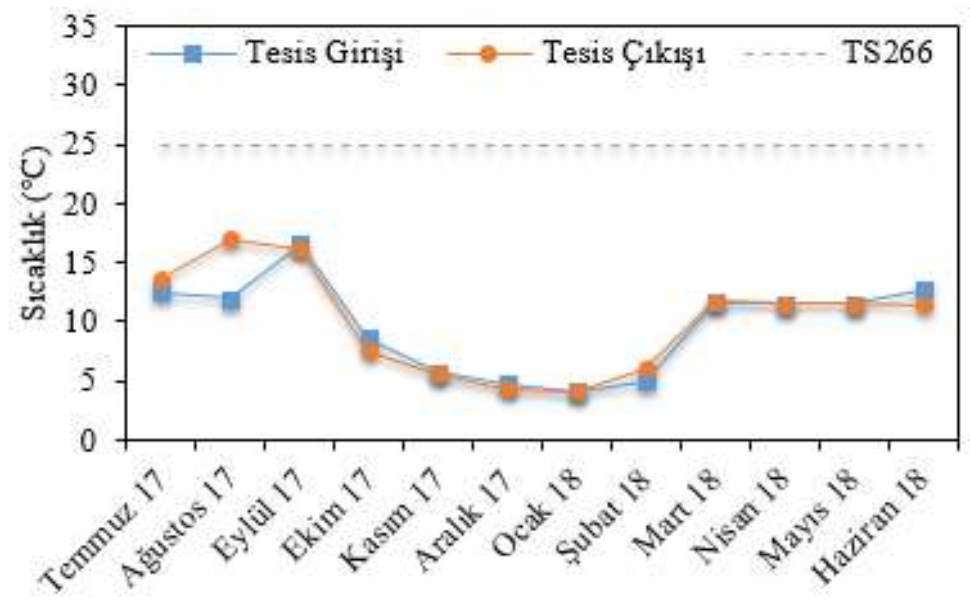

Şekil 3. Su numunelerinin sıcaklık değerlerinin aylara göre değişimi

Şekil 3'e göre, temmuz ayında tesise gelen su numunelerinin sıcaklığı $12,48^{\circ} \mathrm{C}$, çıkış sıcaklığı ise $13,62^{\circ} \mathrm{C}^{\prime}$ dir. Ağustos ile eylül ayları arasında tesise giriş yapan suyun sıcaklığı artarken, tesis çıkışındaki su sıcaklığının azaldığı görülmektedir. Eylül ayından itibaren ocak ayına kadar önemli düzeyde düşüş yaşanan su sıcaklığında, ocak ayında tesise gelen suyun sıcaklığ $14,13^{\circ} \mathrm{C}$, çıkış değeri $4,09^{\circ} \mathrm{C}$ ye kadar düşmüştür. Şubat ayından sonra artış göstermeye başlayan sıcaklık değerlerinden tesise gelen suyun sıcaklığ $15^{\circ} \mathrm{C}$, çıkış değeri $6^{\circ} \mathrm{C}$ ' olarak belirlenmiştir. TS $266^{\prime}$ ya göre $12-25^{\circ} \mathrm{C}$ aralığında olması gerektiği belirtilen sıcaklık değerlerinin sonbahar ve kış mevsimlerini kapsayan ekim, kasım, aralık, ocak, şubat aylarında bu standarda uygun olmadığı görülmektedir. Su sıcaklıkları bölgesel ve mevsimsel nedenlerle azalıp artmaktadır. Bölgedeki havanın kış aylarında soğukluğu ve kış aylarında yağan karlar nedeniyle su sıcaklıkları oldukça düşük olabilmektedir. Ayrıca suyun temin edildiği bitki örtüsünün ormanlarla kaplı olması ve yükseltinin fazla olması gibi nedenler, sıcaklık değerlerinin ortalamanın altına düşmesine neden olabilmektedir $[14,15]$. Elde edilen veriler incelendiğinde yılın diğer aylarında sıcaklık değerlerinin kalite standartlarını karşıladığı göstermektedir.

\subsubsection{Renk parametresine iliş kin bulgular}

Su numunelerinin rengi, sudaki katkı maddelerin ve diğer kirleticilerin varlığına bağımlıdır. Sularda renk tayini, suya bulanıklık veren maddelerin uzaklaştırılmasının ardından suyun gerçek rengini belirlemede kullanılmaktadır. Arıtma tesisinde suyun rengine ilişkin bulgular Şekil 4'de gösterilmiştir. 


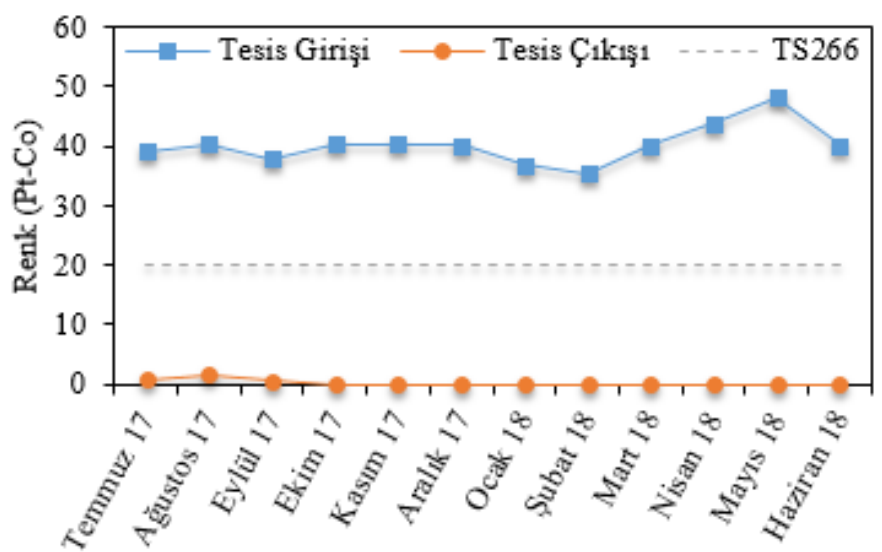

Şekil 4. Su numunelerinin renk değerlerinin aylara göre değişimi

Şekil 4'e göre, temmuz ayında tesise gelen su numunelerinin renk değerleri ortalaması 39,17 PtCo, çıkış değeri ise $0,91 \mathrm{Pt}-\mathrm{Co}$ tır. Tüm aylarda tesis çıkışındaki renk değerlerinin sabit olduğu görülmektedir. Şubat, mart, nisan ve mayıs aylarında tesise gelen suyun renk değerleri sırasıyla 35,52 Pt-Co, 40,22 Pt-Co, 43,80 Pt-Co ve 48,26 Pt-Co olarak belirlenmiştir. Mayıs ayı sonrasında suyun renk değerinin düştüğü gözlemlenmiştir. İçme sularında önemli bir özellik olan renk, temiz sularda berrak, organik madde içeren sularda sarı veya kahverengi, demir ve mangan içeren sularda ise kırmızımtırak veya koyu kahverengidir. Ayrıca su içerisinde çözünmüş ve kollaidal halde bulunan maddelerde sularda renge sebep olmaktadır [16, 17]. Tesis girişindeki suda ölçülen renk değerlerinin şubat ve mayıs ayları arasında artmasının, su kaynağının yüzeysel olması ve kar suları ile ilkbahar yağışlarının yoğunluğu nedeniyle organik ve inorganik maddelerin bu yüzey sularına taşınmasından kaynaklandığ düşünülmektedir. Arıtma tesisine gelen su numunelerinin renk değerlerinin tümü, TS 266'ya göre belirlenen üst limitin çok üzerinde olduğu görülmektedir. Arıtma tesisinde uygulanan işlemler sonucunda ise, tüm aylarda TS 266 ve İnsani Tüketim Amaçlı Sular Hakkında Yönetmeliğe göre renksiz veya renksize yakın su kalitesi standardının sağlandığı belirlenmiştir.

\subsection{Suyun Kimyasal Özelliklerine İlişsin Bulgular}

Araştırmada arıtma tesisine gelen ham su ve arıtma tesisinden çıkan arıtılmış su numunelerinin $\mathrm{pH}$, elektriksel iletkenlik, nitrit, alkalinite, demir, organik madde içeriği, mangan, amonyum, alüminyum, sülfat gibi kimyasal özelliklerine ilişkin değerler karşılaştırılmıştır.

\subsection{1. pH değerlerine iliş̧kin bulgular}

Araştırmada öncelikle suyun içinde çözünmüş maddelerin etkisiyle asit, baz veya nötr özellik göstermesi nedeniyle pH tayini yapılmış ve ölçümlerden elde edilen bulgular Şekil 5'de gösterilmiştir.

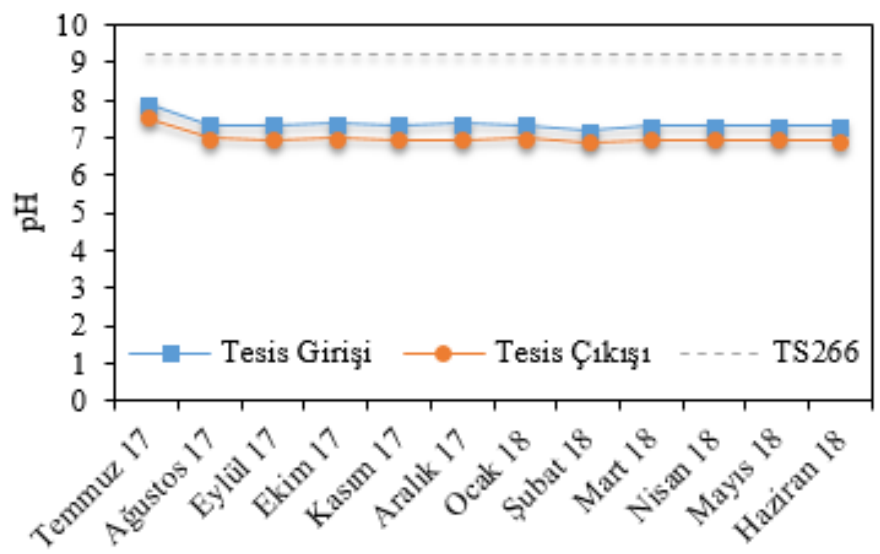

Şekil 5. Su numunelerinin pH değerlerinin aylara göre değişimi 
Şekil 5 incelendiğinde temmuz ayında tesise gelen su numunelerinin $\mathrm{pH}$ değeri 7,9, çıkış pH değeri ise 7,55'tir. Ağustos ayında tesise gelen suyun pH'sının 7,35'e, çıııştaki suyun pH'sının ise 7'ye düştügü görülmüştür. Şubat ayına kadar pH değerlerinin sabit kaldığı, şubat ayında tesise gelen suyun pH'sının 7,36, çıkış pH'sının ise 6,98'e düştügü gözlemlenmiştir. Mart ayında ise giriş ve çıkıştaki su pH'sının tekrar artış göstererek, sabit bir eğilim izlediği belirlenmiştir. Ölçüm yapılan tüm aylarda su numunelerinin içme suyu arıtma tesisi çıkışında $\mathrm{pH}$ değerlerinin azaldığı görülmüştür. Tesis girişinde yaz aylarında $\mathrm{pH}$ değerlerinin daha yüksek olmasının nedeninin, yaz aylarında bitkilerin yüksek hızda fotosentez yaparak $\mathrm{CO}_{2}$ tüketmelerinden kaynaklandığı düşünülmektedir. Kış aylarında ise yağmur sularının taşıdığı maddelerin suya karışması nedeniyle $\mathrm{pH}$ değerinin düştüğü düşünülebilir [18]. Elde edilen bulgular su numunelerinin tesis çıkışındaki pH değerlerinin TS 266 ve İnsani Tüketim Amaçlı Sular Hakkında Yönetmeliğe göre 6,5 ile 9,5 aralığında olduğunu göstermekte olup, diğer bir ifadeyle su kalitesinin $\mathrm{pH}$ açısından uygun olduğu tespit edilmiştir.

\subsubsection{Elektriksel iletkenliğe (EC) ilişkin bulgular}

EC, su numunelerinin içerdiği çözünmüş haldeki tüm iyonların miktarını göstermekte olup yapılan ölçümlerde elde edilen bulgular Şekil 6' da gösterilmiştir.

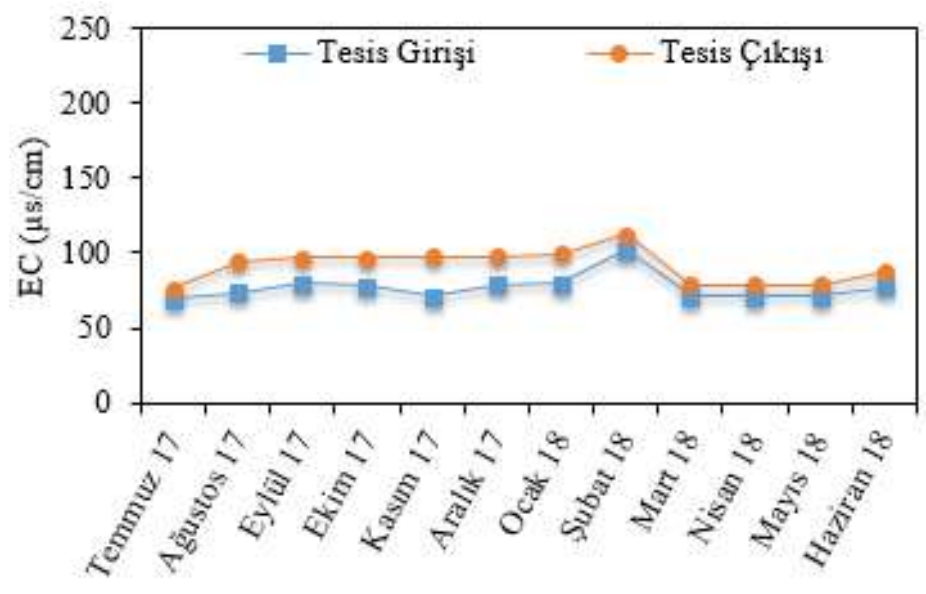

Şekil 6. Su numunelerinin EC değerlerinin aylara göre değişimi

Şekil 6'ya göre temmuz ayında tesise gelen su numunelerinin EC değerleri 69,60 $\mu \mathrm{s} / \mathrm{cm}$, çıkış değeri ise $76,38 \mu \mathrm{s} / \mathrm{cm}$ 'dir. Ağustos ayından sonra elektriksel iletkenliğin ocak ayına kadar sabit bir eğilim izlediği, ocak ayında tesise gelen suyun EC değerlerinin 79,63 $\mu \mathrm{s} / \mathrm{cm}$, çıkış değerinin 99,27 $\mu \mathrm{s} / \mathrm{cm}$ 'ye, şubat ayında ise giriş ve çıkış değerlerinin sırasıyla $102,05 \mu \mathrm{s} / \mathrm{cm}$ ve $112,21 \mu \mathrm{s} / \mathrm{cm}$ 'ye ulaştığ görülmektedir. Tesis giriş suyunda EC değerlerinin ocak ve şubat aylarında azda olsa yükselmesinin nedeni kar yağışlarının artması, tesise giriş yapan suyun EC değerlerinin çıkış suyundan fazla olmasının nedeni ise proseste kullanılan $\mathrm{Al}_{2} \mathrm{SO}_{4}$ olduğu düşünülmektedir [19]. Şekil 6'ya göre ölçüm yapılan tüm aylarda su numunelerinin içme suyu arıtma tesisi çıkışındaki EC değerlerinin az miktarda arttığı görülmüştür. Elde edilen EC değerlerine göre, su numunelerinin tesis çıkışındaki EC değerlerinin TS 266'ya göre $2000 \mu \mathrm{s} / \mathrm{cm}$ sınırının altında olduğu, İnsani Tüketim Amaçlı Sular Hakkında Yönetmeliğe göre ise $2500 \mu \mathrm{s} / \mathrm{cm}$ maksimum sınırın altında olduğu belirlenmiştir.

\subsubsection{Nitrit değerlerine ilişkin bulgular}

Azot ve azotlu maddeler, arıtma tesislerinde önemli bir yere sahip olup arıtma tesisinde suyun nitrit içeriğine ilişkin bulgular Şekil 7'de gösterilmiştir. 


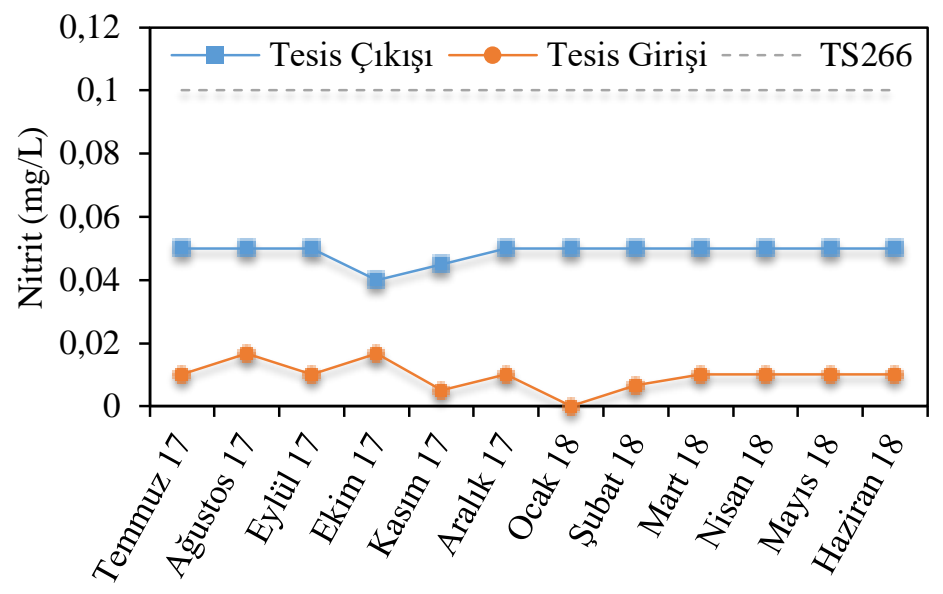

Şekil 7. Su numunelerinin nitrit değerlerinin aylara göre değişimi

Nitrit değerleri her ne kadar düşük ölçülmüş olsa da bölgedeki tarım ve hayvancılık faaliyetlerine bağlı olarak oluştuğu düşünülmektedir [20]. Şekil 7 incelendiğinde, temmuz ayında tesise gelen su numunelerinin nitrit değerleri ortalamasının $0,05 \mathrm{mg} / \mathrm{L}$, çıkış değerinin ise $0,015 \mathrm{mg} / \mathrm{L}$ olduğu belirlenmiştir. Tesis girişindeki suyun nitrit değerlerinin eylül ayında azaldığı, ekim ayında ise artarak sonrasında sabit bir eğilim izlediği, tesis çıkışındaki suyun nitrit değerlerinin ise mart ayına kadar artan ve azalan değerlere sahip olduğu görülmektedir. Ağustos ve ekim aylarında sirasıyla tesise gelen suyun nitrit değerleri $0,05 \mathrm{mg} / \mathrm{L}$ ve $0,04 \mathrm{mg} / \mathrm{L}$, çıkış değerleri ise $0,01 \mathrm{mg} / \mathrm{L}$ ve $0,01 \mathrm{mg} / \mathrm{L}$ 'dir. Şekil 7'ye göre, su numunelerinin tesis giriş ve çıkışında nitrit değerleri arasında farklılık olduğu görülmektedir. Tesis girişindeki nitrit değerlerinin tümünün $0,04-0,05 \mathrm{mg} / \mathrm{L}$ aralığında, tesis çıkışındaki su numunelerinin nitrit değerlerinin ise $0-0,016 \mathrm{mg} / \mathrm{L}$ aralığında olduğu belirlenmiştir. Tesis girişinde bulunan havalandırma ve tesis çıkışında yer alan dezenfeksiyon proseslerinde nitritin parçalanması ile çıkış değerlerinde azalmanın olduğu düşünülebilir. Tüm aylarda, su numunelerinin nitrit içeriklerinin TS 266 ve İnsani Tüketim Amaçlı Sular Hakkında Yönetmeliğe göre sırasıyla üst sınır olarak kabul edilen 0,1 $\mathrm{mg} / \mathrm{L}$ ve $0,5 \mathrm{mg} / \mathrm{L}$ değerlerin altında olduğu tespit edilmiştir.

\subsubsection{Alkalinite}

Alkalinite, suyun asit nötralize etme kapasitesi olarak tanımlanmakta ve suyun içerdiği karbonat, bikarbonat ve hidroksil miktarına göre değişmektedir. Arıtma tesisinde suyun alkalinitesine ilişkin bulgular Şekil 8'de gösterilmiştir.

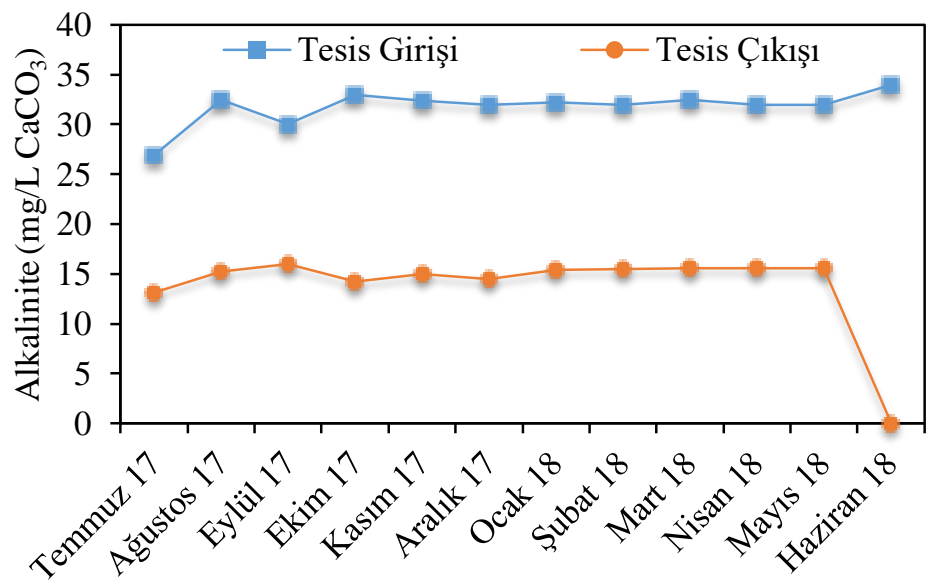

Şekil 8. Su numunelerinin alkalinite değerlerinin aylara göre değişimi

Şekil 8'e göre, temmuz ayında tesise gelen su numunelerinin alkalinite değerleri ortalaması 26,91 $\mathrm{mg} / \mathrm{L} \mathrm{CaCO}$, çıkış değeri ise $13,33 \mathrm{mg} / \mathrm{L} \mathrm{CaCO}_{3}$ 'tür. Ekim ayında tesise gelen suyun alkalinite değeri 
$33 \mathrm{mg} / \mathrm{L} \mathrm{CaCO} 3$ olup, mayıs ayına kadar sabit bir eğilim izlemiştir. Mayıs ayı içerisinde tesise gelen suyun alkalinite değeri artmaya başlamış ve haziran ayında yıllık en yüksek değer olan $34 \mathrm{mg} / \mathrm{L} \mathrm{CaCO}_{3}$ değerine ulaşmıştır. Aksine, tesisten çıkan suyun alkalinite değeri açısından mayıs ayı içerisinde keskin bir azalma görülmüş ve alkalinite tamamen kaybolmuştur. Mayıs ayından itibaren haziran başlangıcında tesis çıkışındaki suyun alkalinite değerinin keskin bir düşüşle sıfıra inmesinin nedeni, ilkbaharda arıtma tesisinin temizlik ve bakıma girmesi ile su borularındaki hızlı ve yavaş karıştırma, durultma havuzlarında biriken çamurların tahliye edilmesinden kaynaklandığı düşünülmektedir [21]. Yılın her ayında, arıtma tesisinin girişindeki su alkalinitesi değerlerinin tesis çıkışında azaldığı belirlenmiştir. Tesis girişindeki alkalinite değerlerinin tümünün $26-34 \mathrm{mg} / \mathrm{L} \mathrm{CaCO}{ }_{3}$ aralığında olduğu gözlemlenmiştir. Tesis çıkışındaki su numunelerinin alkalinite değerlerinin ise $13-16 \mathrm{mg} / \mathrm{L} \mathrm{CaCO}_{3}$ aralığında olduğu belirlenmiştir.

\subsubsection{Demir değerlerine ilişkin bulgular}

Arıtma tesisinde suyun demir değerlerine ilişkin bulgular Şekil 9'da gösterilmiştir.

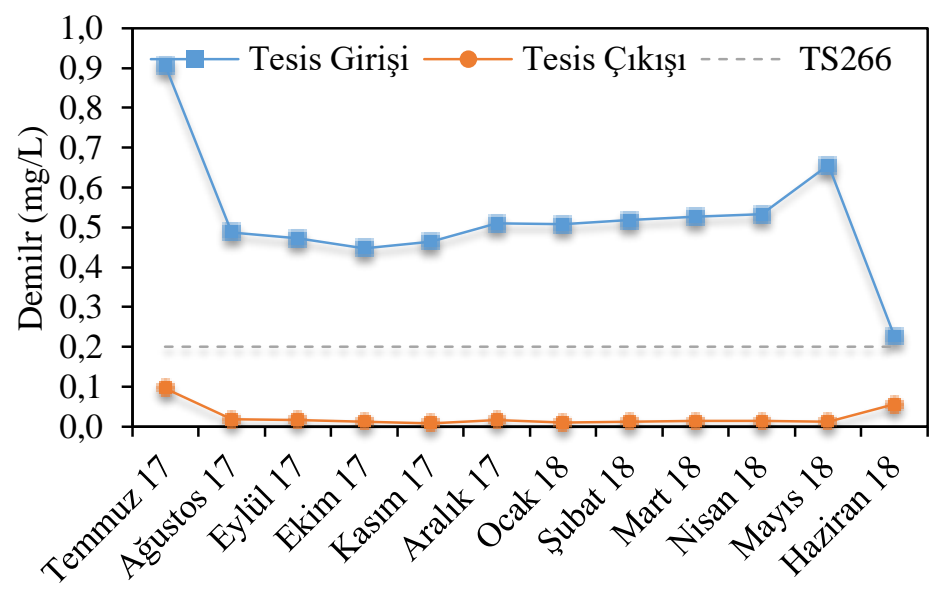

Şekil 9. Su numunelerinin ölçülen demir değerlerinin aylara göre değişimi

Şekil 9 ayrıntılı olarak incelendiğinde, temmuz ayında tesise gelen suyun demir içeriği ortalaması $0,90 \mathrm{mg} / \mathrm{L}$, çıkış değeri ise $0,096 \mathrm{mg} / \mathrm{L}$ 'dir. Nisan ayına kadar belirli oranda artış gösterme eğilimi bulunan demir içeriği mayıs ayında en yüksek değeri olan $0,65 \mathrm{mg} / \mathrm{L}$ 'ye ulaşmıştır. Mayıs ayı içerisinde ise tesise gelen suyun demir içeriğinin hızlı bir düşüşe geçtiği ve haziran ayı başında en düşük değerine ulaştı̆̆ 1 görülmektedir. Tesis çıkışındaki suyun demir içeriği ise yıl boyunca sabit kalmıştır. İlkbahar aylarında yağışların artması ile birlikte yüzey sularının demir içeriğinin artış göstermesi ve demir miktarı artan kaynak sularının, sızıntı ile yüzey sularına karışması nedeniyle nisan ayından itibaren tesis girişindeki suyun demir içeriğinin arttığı düşünülmektedir [22]. Tesis girişindeki demir değerlerinin tümünün $0,22-0,90 \mathrm{mg} / \mathrm{L}$ aralığında olduğu, çıkış değerlerinin ise haziran ve temmuz aylarında sırasıyla $0,056 \mathrm{mg} / \mathrm{L}$ ve $0,096 \mathrm{mg} / \mathrm{L}$ olduğu gözlemlenmiştir. Bu bulgulara göre çıkış suyunda demir içeriklerinin TS 266 ve İnsani Tüketim Amaçlı Sular Hakkında Yönetmeliğe göre üst sınır olarak kabul edilen 0,2 $\mathrm{mg} / \mathrm{L}$ değerinin altında olduğu tespit edilmiştir.

\subsubsection{Organik madde içeriğine ilişkin bulgular}

Organik maddeler sulara bitkiler, insanlar ve hayvanlar tarafından farklı kaynaklardan karışabilmekte ve hijyen açısından tehlike arz etmekte olup arıtma tesisinde suyun organik madde içeriğine ilişkin bulgular Şekil 10'da gösterilmiştir. 


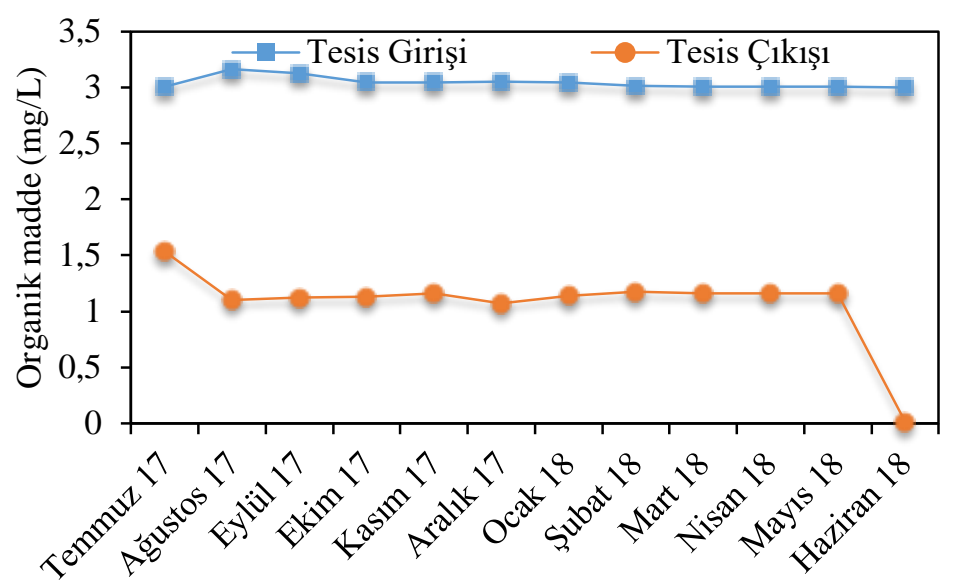

Şekil 10. Su numunelerinin organik madde değerlerinin aylara göre değişimi

Şekil 10'a göre, temmuz ayında tesise gelen suyun organik madde ortalaması $3 \mathrm{mg} / \mathrm{L} \mathrm{O}$, çıkış değeri ise $1,53 \mathrm{mg} / \mathrm{L} \mathrm{O}_{2}$ ' dir. Tesis girişindeki suyun organik madde içeriğinin tüm y1l boyunca neredeyse $3 \mathrm{mg} / \mathrm{L} \mathrm{O} \mathrm{O}_{2}$ değerinde sabit kaldığı görülmektedir. Ancak tesis çıkışındaki suyun organik madde içeriğinin temmuz ayı içerisinde azalma gösterdiği ve mayıs ayına kadar sabit bir eğilim izlediği belirlenmiştir. Mayıs ayı başlangıcında $1,16 \mathrm{mg} / \mathrm{L} \mathrm{O}_{2}$ organik madde içeriği olan su, tesis çıkışında organik madde içeriğini kaybederek, haziran ayında sıfıra düşmüştür. Suyun organik madde içeriğinde mayıs ayında gerçekleşen keskin düşüşün nedeni, ilkbahar ayında arıtma tesisinde bulunan su borularındaki hızlı ve yavaş karıştırma, durultma havuzlarında biriken organik ve inorganik maddelerin oluşturduğu çamurların tahliye edilmesinden kaynaklandığı düşünülmektedir [23]. Ayrıca bu dönemde hızlı kum filtrelerinin hava ve su ile geri yıkama yapılarak temizlenmesi bu düşüşte etkilidir. Tesis girişindeki organik madde değerlerinin tümünün 3-3,5 mg/L $\mathrm{O}_{2}$ aralığında olduğu, çıkış değerlerinin ise temmuz ayında maksimum $1,536 \mathrm{mg} / \mathrm{L} \mathrm{O}_{2}$ olduğu gözlemlenmiştir.

\subsubsection{Mangan değerlerine iliş̧kin bulgular}

Arıtma tesisinde suyun mangan değerlerine ilişkin bulgular Şekil 11'de gösterilmiştir.

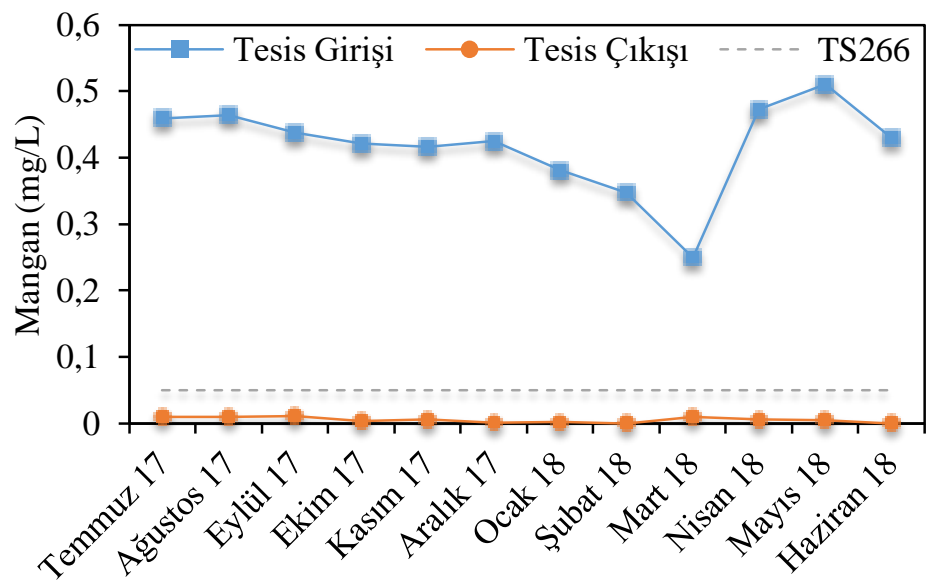

Şekil 11. Su numunelerinin mangan değerlerinin aylara göre değişimi

Şekil 11'e göre, temmuz ayında tesise gelen suyun mangan içeriği ortalaması 0,459 mg/L, çıkış değeri $0,01 \mathrm{mg} / \mathrm{L}$ 'dır. Kış ayları boyunca (aralık, ocak ve şubat) sabit hızda düşüş gösteren mangan miktarının mart ayın başlangıcında en düşük seviye olan $0,25 \mathrm{mg} / \mathrm{L}$ 'yi bulduğu görülmektedir. Mart ve nisan ayları boyunca ise, tesise gelen suyun mangan içeriğinin artarak mayıs ayı başlangıcında en yüksek değer olan $0,51 \mathrm{mg} / \mathrm{L}$ 'ye ulaştığı belirlenmiştir. Tesis çıkışındaki suyun mangan içeriğinin ise, tüm yıl boyunca en fazla $0,0113 \mathrm{mg} / \mathrm{L}$ değerine ulaştığı, haziran ayında ise sıfira düştüğü gözlemlenmiştir. 
İlkbahar aylarında karların erimesi ve yağışların toprağa daha fazla miktarlarda düşmesi, bu yağışların da topraktan yüzeysel sulara karışması nedeniyle bu aylarda tesis girişindeki suyun mangan değerlerinin az miktarda da olsa arttığı söylenebilir. Şekil 11 incelendiğinde su numunelerinin tesis giriş ve çıkışında mangan değerleri arasında önemli farklılıklar olduğu görülmektedir. Tesis girişindeki mangan değerlerinin tümünün $0,25-0,51 \mathrm{mg} / \mathrm{L}$ aralığında olduğu, çıkış değerlerinin ise temmuz, ağustos ve eylül aylarında maksimum $0,01 \mathrm{mg} / \mathrm{L}$ olduğu gözlemlenmiştir [24]. Bu bulgulara göre tüm aylarda, çıkış sularından elde edilen su numunelerinin mangan içeriklerinin TS 266 ve İnsani Tüketim Amaçlı Sular Hakkında Yönetmeliğe göre üst sınır olarak kabul edilen $0,05 \mathrm{mg} / \mathrm{L}$ değerinin altında olduğu tespit edilmiştir.

\subsubsection{Amonyum değerlerine ilişkin bulgular}

Arıtma tesisinde suyun amonyum değerlerine ilişkin bulgular Şekil 12'de gösterilmiştir.

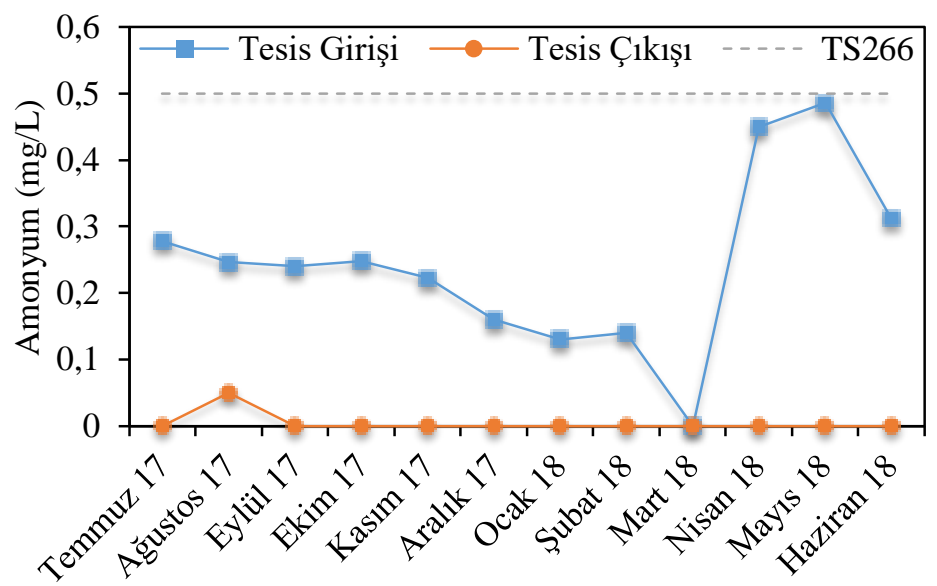

Şekil 12. Su numunelerinin amonyum değerlerinin aylara göre değişimi

Şekil 12'ye göre, temmuz ayında tesise gelen suyun amonyum içeriğinin ortalaması 0,278 mg/L, çıkış suyunda amonyum bulunmamaktadır. Ekim ve ocak ayları arasında tesise gelen suyun amonyum içeriğini düşüşe geçtiği ve mart ayında sıfırı bulduğu görülmektedir. Ancak mart ayı itibarıyla keskin bir yükselişe geçen amonyum miktarı, mayıs ayı başlangıcında $0,5 \mathrm{mg} / \mathrm{L}$ 'ye ulaşmış, haziran ayında ise tekrar $0,31 \mathrm{mg} / \mathrm{L}$ 'ye düşmüştür. Tesisten çıkan suyun amonyum değerinin ise, yalnızca ağustos ayında $0,05 \mathrm{mg} / \mathrm{L}$ 'ye ulaştığı, yılın diğer tüm aylarında ise sıfır değerinde sabit bir eğilim izlediği belirlenmiştir. Mart ayından itibaren karların erimesi, yağışların artış göstermesi ve bölgede tarım ve hayvancılığın en önemli geçim kaynağı olması nedeniyle azotlu gübre kullanımı ile toprakta bulunan azotlu maddelerin çözülerek, suyun bünyesine geçmesi ve yüzeysel suya taşınması nedeniyle bu dönemde amonyum miktarının artış gösterdiği öngörülmektedir [25]. Tesis girişindeki amonyum değerlerinin tümünün 0 $0,5 \mathrm{mg} / \mathrm{L}$ aralığında olduğu, çıkış değerlerinin ise ağustos ayında maksimum $0,05 \mathrm{mg} / \mathrm{L}$ olduğu gözlemlenmiştir. Bu bulgulara göre, su numunelerinin amonyum içeriklerinin TS 266 ve İnsani Tüketim Amaçlı Sular Hakkında Yönetmeliğe göre üst sınır olarak kabul edilen $0,5 \mathrm{mg} / \mathrm{L}$ değerinin altında olduğu, yalnızca mayıs ayında sınır değerinde olduğu tespit edilmiştir.

\subsubsection{Alüminyum değerlerine ilişkin bulgular}

Arıtma tesisinde suyun alüminyum değerlerine ilişkin bulgular Şekil 13'de gösterilmiştir. 


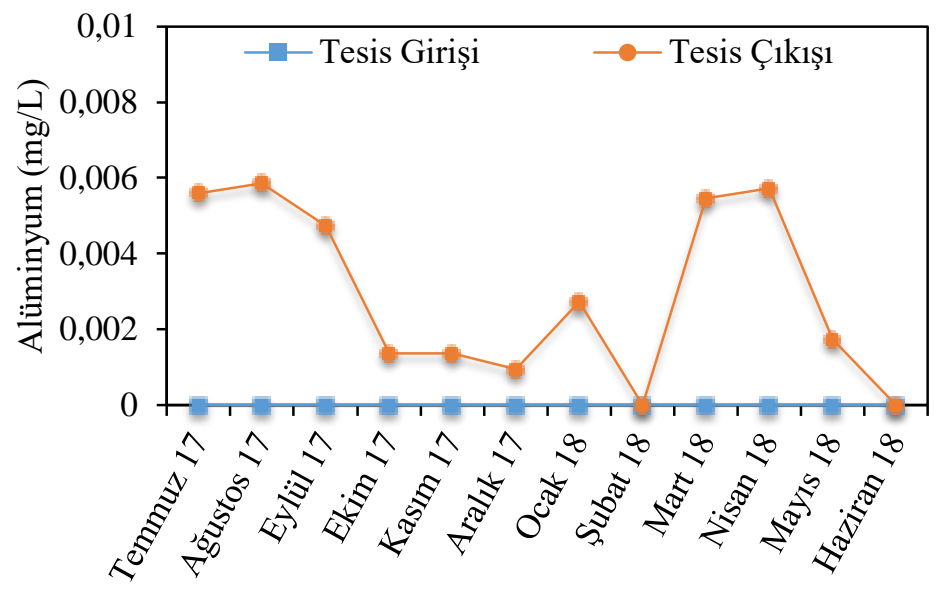

Şekil 13. Su numunelerinin alüminyum değerlerinin aylara göre değişimi

Şekil 13'e göre, temmuz ayında giriş suyunda alüminyum bulunmazken, çıkış suyunda alüminyum değerlerinin ortalamas $0,0056 \mathrm{mg} / \mathrm{L}$ 'dir. Ağustos ayı başlangıcında $0,058 \mathrm{mg} / \mathrm{L}$ ile tüm yılın en yüksek alüminyum içeriğine rastlanmış, diğer aylarda ise sabit bir eğilime sahip olduğu görülmüştür. Tesis girişindeki suda ise tüm yıl boyunca alüminyum gözlemlenmemiştir. İlkbahar aylarında tesis girişindeki suyun renk ve bulanıklık değerlerinin artması sonucunda arıtmada renk ve bulanıklığı gidermek amacıyla kullanılan $\mathrm{Al}_{2} \mathrm{SO}_{4}$ '’n, suyun tesis çıkışındaki alüminyum değerlerini arttırdığı düşünülmektedir [26]. Tesis girişindeki alüminyum bulunmadığı, çıkış değerlerinin ise, maksimum 0,005-0,006 mg/L aralığında olduğu gözlemlenmiştir. En yüksek alüminyum çıkış değerleri temmuz, ağustos, mart ve nisan aylarında tespit edilmiştir. Bu bulgulara göre tüm aylarda, su numunelerinin alüminyum içeriklerinin TS 266 ve İnsani Tüketim Amaçlı Sular Hakkında Yönetmeliğe göre üst sınır olarak kabul edilen $0,2 \mathrm{mg} / \mathrm{L}(200 \mu \mathrm{g} / \mathrm{L})$ değerinin altında olduğu tespit edilmiştir.

\subsubsection{Sülfat değerlerine ilişkin bulgular}

Arıtma tesisinde suyun sülfat değerlerine ilişkin bulgular Şekil 14'de gösterilmiştir.

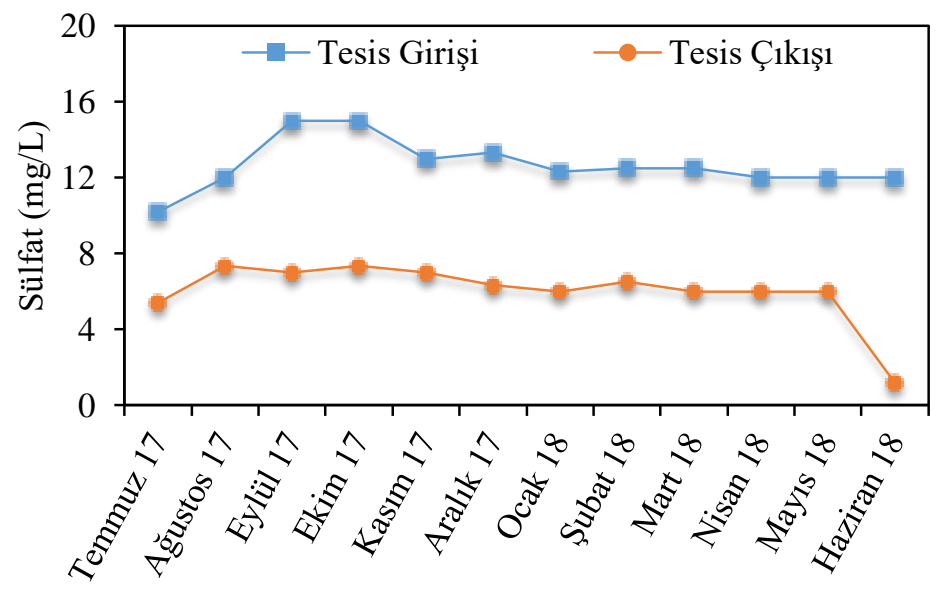

Şekil 14. Su numunelerinin sülfat değerlerinin aylara göre değişimi

Şekil 14'e göre, temmuz ayında tesise gelen suyun sülfat içeriğinin ortalaması 10,20 mg/L, çıkış değeri ise $5,40 \mathrm{mg} / \mathrm{L}$ 'dir. Tesise gelen suyun sülfat içeriği eylül ayına kadar artış göstererek en yüksek değeri olan $15 \mathrm{mg} / \mathrm{L}$ 'ye ulaşmış ve eylül ayı boyunca bu değerde sabit kalmıştır. Ekim ayının başlangıcından itibaren azalmaya başlayan sülfat içeriğinin nisan ayına kadar bu eğilimi sürdürdüğü ve nisan ayından itibaren haziran ayına kadar $12 \mathrm{mg} / \mathrm{L}$ 'de sabit kaldığı gözlemlenmiştir. İlkbahar aylarında (mart, nisan ve mayıs) $6 \mathrm{mg} / \mathrm{L}$ değerinde sabit kalmış, mayıs ayından itibaren haziran ayı başlangıcına kadar keskin bir düşüşle y1lı 1,16 mg/L ile tamamlamıştır. İlkbahar aylarında tesis girişindeki suyun 
renk ve bulanıklık değerlerinin artması sonucunda arıtmada renk ve bulanıklığı gidermek amaciyla $\mathrm{Al}_{2} \mathrm{SO}_{4}$ kullanılmaktadır. Yaz aylarına doğru bulanıklığın azalması nedeniyle $\mathrm{Al}_{2} \mathrm{SO}_{4}$ kullanımının da azaldığı ve bu aylarda sülfat miktarının tesis çıkışında düştüğü söylenebilir [27]. Tesis girişindeki sülfat değerlerinin tümünün 10-15 mg/L aralığında olduğu, çıkış değerlerinin ise maksimum 7,33 mg/L olduğu gözlemlenmiş̧tir. En yüksek sülfat çıkış değerleri ağustos, eylül, ekim ve kasım aylarında tespit edilmiştir. Bu bulgulara göre tüm aylarda, su numunelerinin sülfat içeriklerinin TS 266 ve İnsani Tüketim Amaçlı Sular Hakkında Yönetmeliğe göre üst sınır olarak kabul edilen $250 \mathrm{mg} / \mathrm{L}$ değerinin altında olduğu tespit edilmiştir.

\section{Sonuç ve Öneriler}

Bu araştırmada, Kars ili Sarıkamış ilçesinde bulunan İçme Suyu Arıtma Tesisine Temmuz 2017-Haziran 2018 tarihleri arasında gelen su numunelerinin fiziksel ve kimyasal su kalitesinin belirlenmesi amaçlanmıştır.

$\mathrm{pH}$ açısından en yüksek değerler temmuz ayında giriş $\mathrm{pH}$ değeri 7,9, çıkış $\mathrm{pH}$ değeri ise 7,55 olarak ölçülmüştür. Elektriksel iletkenlik için en yüksek değerler ise ocak ve şubat aylarında görülmüştür. Ocak ayında tesis girişinde EC $79,63 \mu \mathrm{s} / \mathrm{cm}$, tesis çıkışında ise $99,27 \mu \mathrm{s} / \mathrm{cm}$ olarak, şubat ayında ise giriş ve çıkış değerleri sırasıyla $102,05 \mu \mathrm{s} / \mathrm{cm}$ ve $112,21 \mu \mathrm{s} / \mathrm{cm}$ olarak belirlenmiştir. Bulanıklık değerleri mayıs aylarında en yüksek seviyeye ulaşmış ve bu ayda tesise gelen suyun bulanıklık değeri 71,52 NTU, çıkış değeri 0,98 NTU olarak ölçülmüştür. Diğer aylarda tesis giriş ve çıkış değerlerinin sabit bir eğilime sahip olduğu görülmüştür. Sıcaklık açısından en yüksek değerler yaz mevsimi sonlarını kapsayan ağustos ve eylül aylarında, en düşük değerler ise sonbahar ve kış aylarını kapsayan ekim, kasım, aralık, ocak ve şubat aylarında görülmüştür. Renk açısından en yüksek değer mayıs ayında 48,26 Pt-Co olarak ölçülmüştür.

Nitritin en düşük giriş değerlerinin görüldüğü ekim ve kasım ayları dışındaki aylarda sabit bir eğilim izlediği görülürken alkalinite açısından en yüksek tesis giriş değerleri ekim ve haziran aylarında görülmüştür. Demir için en yüksek değerler mayıs ayında görülmüş olup mayıs ayı sonrası yaz mevsiminde demir değerlerinin azalan eğilime sahip olduğu belirlenmiştir. Tesis çıkış değerlerinin ise haziran ve temmuz aylarında maksimum $0,056 \mathrm{mg} / \mathrm{L}$ ve $0,096 \mathrm{mg} / \mathrm{L}$ olduğu gözlemlenmiştir. Organik madde değerleri en yüksek ağustos ayında görülürken, diğer aylarda sabit bir eğilim izlemiştir. Tesis girişindeki organik madde değerlerinin tümünün 3-3,5 mg/L $\mathrm{O}_{2}$ aralığında olduğu, çıkış değerlerinin ise temmuz ayında maksimum $1,536 \mathrm{mg} / \mathrm{L} \mathrm{O}_{2}$ olduğu gözlemlenmiştir. Mangan ve alüminyum miktarları açısından en yüksek değerler sırasıyla nisan ve mayıs ayları ile temmuz, ağustos, mart ve nisan ayları olarak tespit edilmiştir. Amonyum miktarı için en yüksek değerler yaz aylarında gerçekleşmiştir. Sülfat miktarı için en yüksek değerler ise eylül, ekim ve kasımda görülmüş, kasım ayı sonrasında sülfat değerleri sabit bir eğilim izlemiştir.

Sonuç olarak ham ve arıtılmış su için çalışma yapılan zaman dilimlerinde TS 266 ve İnsani Tüketim Amaçlı Sular Hakkında Yönetmeliğe göre sülfat içeriği açısından kalite standardının sağlandığı belirlenmiştir. Bu çalışma özellikle soğuk iklime sahip olan yerleşim birimlerinde içme suyu arıtımında karşılaşılabilecek sorunlara yol göstermek amacıyla yapılmış olup, literatüre bu tarz bölgelerde karşılaşılabilecek sorunlar hakkında katkıda bulunacaktır.

\section{Teşekkür}

Çalışmada destek ve yardımlarından ötürü Atatürk Üniversitesi Çevre Mühendisliği Bölümü, Sarıkamış Belediye Başkanlığı Çevre Koruma ve Kontrol Müdürlügü ve değerli personellerine teşekkür ederiz.

\section{Yazarların Katkısı}

Çalışmada her bir yazar farklı analizlerin yapılmasında ve yorumlanmasında çalışmışlardır.

\section{Çıkar Çatışması Beyanı}

Yazarlar arasında herhangi bir çıkar çatışması bulunmamaktadır. 


\section{Araştırma ve Yayın Etiği Beyanı}

Yapılan çalışmada araştırma ve yayın etiğine uyulmuştur.

\section{Kaynaklar}

[1] Chaplin M. 2001. Water: its importance to life. Biochemistry and Molecular Biology Education, 29: 54-59.

[2] Devlet Su İşleri Genel Müdürlüğü (DSI). (2014). Toprak su kaynakları (çevrimiçi). http://www.dsi.gov.tr/toprak-ve-su-kaynaklari (Erişim tarihi: 29.11.2018).

[3] WWAP (United Nations World Water Assessment Programme)/UN-Water, 2018. The United Nations World water development report 2018: Nature-Based Solutions for Water. Paris, UNESCO.

[4] Ünal S. 2015. Nihai kullanım amacına göre uygulanan membran prosesler ve diğer su arıtma yöntemleri ile içme ve proses suyu üretiminin maliyet analizi. Yüksek Lisans Tezi, İstanbul Teknik Üniversitesi Fen Bilimleri Enstitüsü, İstanbul.

[5] Günşen U., Anar Ş., Gündüz H. 2000. Uludağ' daki su kaynaklarının fiziksel, kimyasal ve mikrobiyolojik özellikleri. Süleyman Demirel Üniversitesi Tıp Fakültesi Dergisi, 7 (2): 21-24.

[6] Dönderici Z.S., Dönderici A., Başarı F. 2010. Kaynak sularının fiziksel ve kimyasal kaliteleri üzerine bir araştırma. Türk Hijyen ve Deneysel Biyoloji Dergisi, 67 (4): 167-172.

[7] European Communities, 2010. Standards for drinking water quality (No. 2) Regulations 2007 (S.I. 278 of 2007).

[8] Koçak Ö. 2007. Erzurum il merkezindeki içme ve kullanma sularının kimyasal, fiziksel ve mikrobiyolojik kalitesi. Yüksek Lisans Tezi, Selçuk Üniversitesi Sağlık Bilimleri Enstitüsü, Konya.

[9] Arora P. 2017. Water resources and management: physical, chemical and biological characteristics of water. Kurukshetra University, India.

[10] MEB, 2016. Gıda teknolojisi: Su. Ankara: Milli Eğitim Yayınları.

[11] TS 266, 2005. İnsanî tüketim amaçlı sular. Türk Standartları Enstitüsü, Ankara.

[12] Sarıkamış (KARS) İçme suyu arıtma tesisi işletme ve bakım kitabı.

[13] American Public Health Association. Standard methods for the examination of water and wastewater. Vol. 2. American Public Health Association., 1915.

[14] Şen B., Gölbaşı S. 2008. Hazar Gölü'ne dökülen Kürk Çayı'nın bazı fiziksel ve kimyasal özellikleri. Ege Üniversitesi Su Ürünleri Dergisi, 25 (4): 353-358.

[15] Tepe Y., Ateş A., Mutlu E. Töre Y. 2006. Hasan Çayı (Erzin-Hatay) su kalitesi özellikleri ve aylık değişimleri. Ege Üniversitesi Su Ürünleri Dergisi, 23: 149-154.

[16] Sümer B. 1992. Su Temini ve Çevre Sağlığı. İTÜ Sakarya Mühendislik Fakültesi Matbaası, 2427.

[17] Dayığlu H., Özyurt M.S., Bingöl N., Yıldız C. 2004. Kütahya ili içme sularının bazı fiziksel, kimyasal ve bakteriyolojik özellikleri. Dumlupınar Üniversitesi Fen Bilimleri Enstitüsü Dergisi; 7: 71-90.

[18] Mutlu E., Yanık T., Demir T. 2013. Horohon Deresi (Hafik-Sivas) su kalitesi özelliklerinin aylık değişimleri. Alınteri Zirai Bilimler Dergisi, 25 (B): 45-57.

[19] Kıvrak E. 2011. Karamuk Gölü (Afyonkarahisar) fitoplankton kommunitesinin mevsimsel değişimi ve bazı fiziko-kimyasal özellikleri. Ege Üniversitesi Su Ürünleri Dergisi, 28 (1): 9-19.

[20] Yetiş R., Atasoy A., Demir Yetiş A., Yeşilnacar M. 2018. Balıklıgöl Havzası su kaynaklarının nitrat ve nitrit seviyelerinin belirlenmesi. Çukurova Üniversitesi Mühendislik ve Mimarlık Fakültesi Dergisi, 33 (1): 47-54.

[21] Ustaoğlu M.R., Balık S., Şipal U.G., Mis D.Ö., Aygen C. 2010. Buldan Baraj Gölü (Denizli) planktonu ve mevsimsel değişimi. Su Ürünleri Dergisi, 27 (3): 113-120.

[22] Çak N., Pulatsü S. 2003. Yukarı Sakarya Nehri'nde azot fraksiyonları ile toplam demir ve silikat konsantrasyonlarının mevsimsel değişimi. Tarım Bilimleri Dergisi, 9 (4): 408-414.

[23] Tokatlı C., Esengül K., Arslan N., Emiroğlu Ö., Çiçek A., Dayığlu H. 2016. Emet Çayı su kalitesinin mevsimsel değişimi. Uludağ University Journal of The Faculty of Engineering, 21 (2): 9-24. 
[24] Bayram A. 2011. Harşit çayı su kalitesinin mevsimsel değişiminin incelenmesi ve askı madde konsantrasyonunun yapay sinir ağları yöntemi ile tahmin edilmesi. Doktora Tezi, Karadeniz Teknik Üniversitesi Fen Bilimleri Enstitüsü, Trabzon.

[25] Beyhan T.A.Ş. 2011. Gaga Gölü (Ordu, Türkiye) su kalitesinin incelenmesi. Karadeniz Fen Bilimleri Dergisi, 2 (1): 43-61.

[26] Seval A., Fındık Ö. 2018. Nevşehir İli için Kızılırmak Nehri’nin içme suyu potansiyelinin araştırılması. Nevşehir Bilim ve Teknoloji Dergisi, 7 (2): 214-222.

[27] Taş B., Candan A.Y., Can Ö., Topkara S. 2010. Ulugöl (Ordu)'ün bazı fiziko-kimyasal özellikleri. Journal of FisheriesSciences.com, 4 (3): 254-263. 